\title{
Grammatical Errors on BIPA Students (Indonesian Language for Foreign Speakers) in Writing Practice for Beginner Level
}

\author{
Hespi Septiana ${ }^{1, *}$ Warsita N. Ardiyanti ${ }^{1}$ Stawomir Dudek ${ }^{2}$ \\ ${ }^{1}$ Universitas Negeri Surabaya, Indonesia \\ ${ }^{2}$ Adam Mickiewicz University, Poland \\ *Corresponding author. Email: hespiseptiana@unesa.ac.id
}

\begin{abstract}
Writing skill is one of the active language skills that is important in expressing ideas, thoughts, and feelings. Writing is also a difficult thing for BIPA students, especially for beginners with academic goals. The Indonesian language has the standard Indonesian grammar that BIPA students should understand with the process that is not relatively easy. In general, the BIPA students experienced several errors repeatedly in writing, such as word choices, sentence structures, affixes, and word mixing. In fact, most of their issues are in affixes. The students get confused when the affix of memeets the base verb, for instance: $(m e-)+p u k u l$ will be menpukul or (me-)+makan will be memakan. This study will analyze some examples of errors more profound in the final exam from BIPA students in the beginner class. Most of them are from Thailand, Egypt, France, and Timor Leste. Their backgrounds are from undergraduate students to doctoral students who are interested in learning Indonesian studies in their country or planning to study in some universities in Indonesia.
\end{abstract}

Keywords: Writing, Grammatical errors, Beginner level.

\section{INTRODUCTION}

Department of Indonesian Language for Foreign Speakers (BIPA) at Universitas Negeri Surabaya has developed and innovated through various teaching given by educators to students since 2001. It does not only offer four language skills learning, but it also teaches Indonesian grammar in-depth for students who have academic goals such as research writings or final assignments. Some students take the BIPA program with their academic goals from Asian studies programs that focus on the Indonesian language and the culture at their own home university. Therefore, they must write a thesis or final assignment in Indonesian language at the end of the semester. Thus, they need to understand Indonesian grammar well and correctly, especially in writing.

In essence, according to the Great Dictionary of the Indonesian Language (red: Kamus Besar Bahasa Indonesia, KBBI), various languages have differences in the topic of being discussed. The language variety is divided into four, namely: regional variety, standard variety, literary variety, and slang variety [1]. However, referring to the BIPA students who focus on academics, the standard variety is the most crucial component that must be mastered to fulfill the quality of their scientific writing.

Standard language variety has predetermined rules and regulations that cannot be changed at any time according to individual wills. In addition, the form of the standard variety has regularity and logic. These characteristics cause the variety of standard languages to have dynamic stability and intelligence [1].

Due to the fact that several standards must be fulfilled in writing, BIPA students often experience some errors, including spellings, sentence structures, affixes used, and compounds between the standard variety and the slang variety. Ideally, the standard variety rules must be in accordance with the regulations set by the Language Center. All standards include vocabularies that have been listed in the KBBI, spellings listed in the General Guidelines for Indonesian Spelling (red: Pedoman Umum Ejaan Bahasa Indonesia, PUEBI), and sentence structures in the Standard 
Indonesian Grammar (red: Tata Bahasa Baku Bahasa Indonesia, TBBBI).

Language skills will not be easy to absorb just from understanding rules or standards that have been set. BIPA students need to carry out some disciplined exercises in the use of the Indonesian language so that the students will be skilled at using Indonesian grammar correctly and adequately. It can be applied to hone the BIPA students' language skills in Indonesian grammar through a written text. An individual requires a lot of practice to have a skill in languages and master in writing. In this process, it is common to find any errors in the arrangement of letters and grammatical [2].

Language errors have two limitations, namely (1) goof: there is an error in a sentence or speech, (2) gooficon: a type of error that focuses on grammar, and (3) goofing: all language errors. This article will analyze some written language errors for basic level students who have academic goals that are not in accordance with the Indonesian language rules [3]. The language errors are part of an oral or written text that is not in accordance with the norms of the language used [4]. As stated in the opinion above, Siagian claimed that the language errors in BIPA learning are natural and part of the learning process [5]. However, several following factors can cause BIPA students to have often difficulty practicing writing or speaking in Indonesian. Firstly, the students still lack at mastering Indonesian grammar. Secondly, they do not understand the meaning of words or sentences. Thirdly, they have not mastered the linguistic units for arranging the proper and correct sentence structure. Lastly, they are still influenced by their first language.

The common language errors made by international students are at the level of understanding and production [6]. At the level of understanding, the BIPA students still have some difficulties in understanding homonyms, such as the word "pukul" which refers to time; on the other hand, another "pukul" word means to a punch to attack something/ someone. Next, at the level of production, the BIPA students still have difficulty writing and pronouncing Indonesian words and sentences in accordance with applicable rules.

\section{METHODS}

This study process was carried out for one semester. The language error analysis was a research process that included activities of collecting error samples, identifying the variety of errors, discussing the errors, classifying the errors, and evaluating the seriousness level of the errors that have been found [7].

Descriptive qualitative research was used in this study. The descriptive qualitative method was also used in this study in order to examine the natural state by describing in detail based on the data found [8].
According to Tarigan, the following are the steps implemented to analyze language errors on BIPA students. The data used were test results and writing assignments of BIPA students for a beginner in total of 10 students.

First, researchers discussed several errors or mistakes include spelling, grammar, and compound/ mixing the diction with other languages. Eventually, the researchers described the cause of the errors. Next, the researchers analyzed the estimated grammatical errors that BIPA students often made at the basic level (beginner). Finally, the researchers provided corrections for each student error according to the Indonesian language standards [9].

\section{RESULTS AND DISCUSSION}

The data used in the analysis were the BIPA students at the primary level who focus on their academic goals. The writings were the results of the final assignment carried out in January 2021.

There were several language errors in their writings, including inaccurate diction, problematic sentence structures, inappropriate/ incorrect affixes, and mixing of standard and slang language.

Table 1. Language errors and the examples

\begin{tabular}{|c|c|}
\hline $\begin{array}{c}\text { Language } \\
\text { Errors }\end{array}$ & Examples of Sentences \\
\hline Diction & $\begin{array}{l}\text { 1. Pria ini memilik rambuat hitam } \\
\text { (This man has black hair) } \\
\text { 2. Saya mau ulang tahun di café (I } \\
\text { will have a birthday at the café) } \\
\text { 3. Saya dukuk id sana (I sit there) } \\
\text { 4. Saya pergi ke pasar memukul } 6 \\
\text { pagi (I went to the market at } 6 \text { a.m.) } \\
\text { 5. Aku pikir aku tidak suka pesta } \\
\text { terlalu (I think I do not like a party too) }\end{array}$ \\
\hline $\begin{array}{l}\text { Sentence } \\
\text { structure }\end{array}$ & $\begin{array}{l}\text { 1. Buku saya sedang membaca (My } \\
\text { book is reading) } \\
\text { 2. Baju baru menpakai oleh saya } \\
\text { (New clothes wear by me) } \\
\text { 3. Sylvia mengkhayal amat yang } \\
\text { indah (Sylvia is imagining really that } \\
\text { beautiful) }\end{array}$ \\
\hline Affix & $\begin{array}{l}\text { 1. Anda menakan nasi (You eat rice) } \\
\text { 2. Saya sedang menbaca buku baru } \\
\text { (I am reading a new book) } \\
\text { 3. Saya menpakai sepatu putih (I } \\
\text { wear white shoes) } \\
\text { 4. Rifki menprotes ibunya (Rifki }\end{array}$ \\
\hline
\end{tabular}




\begin{tabular}{|l|l|}
\hline Mixing & $\begin{array}{l}\text { refutes his mother) } \\
\text { (Father is planting the tomato) } \\
\text { 6. Bapak menukul ular dengan kayu } \\
\text { (Father hits the snake with a wood) }\end{array}$ \\
\hline $\begin{array}{l}\text { 1. Di pikir saya, keluarga saya tidak } \\
\text { perlu pesta ulang tahun kerana hanya } \\
\text { kami tinggal bersama.(In my mind, my } \\
\text { family does not need a birthday party } \\
\text { because it is just us living together) }\end{array}$ \\
$\begin{array}{l}\text { 2. Sebentar lagi udah mau hari ulang } \\
\text { tahun saya. (Soon, it will be my } \\
\text { birthday) } \\
\text { 3. Bukit Bintang yang di atas gunung } \\
\text { biar bisa lihat kota (Bukit Bintang on } \\
\text { top of the mountain so that I can see } \\
\text { the city) }\end{array}$ \\
\hline
\end{tabular}

The first error that often appears is a diction error whose arrangement is not entirely correct, and there are some missing letters. Also, there are several mistakes in word choices. It can affect the reader's understanding and interfere with the clarity of information [10].

\subsection{Diction Errors}

In the sentence of pria ini memilik rambuat hitam (this man has black hair), there is an inappropriate use of 'memilik' and 'rambuat'. The word 'memilik' is supposed to be 'memiliki' (has), and 'rambuat' word becomes 'rambut' (hair). If the word 'rambuat' is written, it will cause an ambiguity to the 'rambut' word. In Indonesian, there is also rambutan word that makes sense to be included in the context of the sentence.

In the sentence of saya mau ulang tahun di café, the students chose to use a foreign spelling that is café. They possibly did not know that word has been absorbed in Indonesian into kafe. Furthermore, the sentence of saya dukuk id sana also provides misunderstanding of information because the word 'dukuk' does not exist in Indonesian. Meanwhile, the word ' $i d$ ' has the same meaning as the Eid holiday.

In the sentence of saya pergi ke pasar memukul 6 pagi, there is a misunderstanding with the use of meaffix with the base verb of 'pukul'. Based on the context of the sentence, the students were asked to write sentences with 'memukul' word. However, the students thought that the word could also be used in the context of describing time.

Moreover, in the sentence of aku pikir aku tidak suka pesta terlalu, the students put 'terlalu' which means 'sangat' (really) is not entirely correct in the context of the sentence. The word 'terlalu' can be used before an adjective. Therefore, the sentence is supposed to be aku pikir aku tidak terlalu suka pesta (I think I don't really like a party).

\subsection{Sentence Structure Errors}

In the sentence of buku saya sedang membaca, the BIPA students tried to write an active sentence, yet the structure used is incorrect. The sentence makes no sense because the subject that does a reading activity is ' $b u k u$ saya' (my book). The sentence is supposed to be saya sedang membaca buku (I am reading a book) or saya membaca buku (I read a book).

Further, in the sentence of baju baru menpakai oleh saya, the BIPA students were supposed to write the sentence saya memakai baju baru into the passive sentence. However, there are some errors in the placement of the sentence structures that confuse the meaning. So the passive form of the sentence should be baju baru saya pakai (new clothes are wore by me).

Then, the sentence of Sylvia mengkhayal amat yang indah has ambiguous meaning. This is because the sentence requires an object to be complete. Besides, the word 'amat' must be accompanied by an adjective without being separated by 'yang', so it is supposed to be Slyvia mengkhayal rumah yang amat indah (Slyvia imagines a very beautiful house).

\subsection{Affix Errors}

According to the six examples of sentences taken from students' writings, the researchers found structured errors in the placement of me- affix such as menakan, menbaca, menpakai, menprotes, mentanam, and menukul. The variety of me- affixes confuses students. Affixes are supposed to be merged into the verbs such as memukul, menanam, and memakai. However, they are practically generalized without paying attention to the fusion process between $m e$ - affix and the base verb with the initials of $k, t, s$, and $p$. Also, the students did not understand the other types of affixes that are memused for verbs that begin with the letters of $b, m, f, p$, and $v$, such as the words of menakan to be memakan and menbaca to be membaca.

\subsection{Word Mixing Errors}

In the sentence of Di pikir saya, keluarga saya tidak perlu pesta ulang tahun kerana hanya kami tinggal bersama, the words of 'di pikir' and 'kerana' are a slang word and the Malay language. The word of 'Di pikir' does not exist in the academic language writing for expressing an opinion. The sentence is supposed to be changed into 'Dalam keluarga saya tidak terlalu penting melaksanakan pesta ulang tahun karena kami tinggal bersama or kami tidak tinggal berjauhan' (It is not really necessary to have a birthday party in my 
family because we live together or we do not live far apart).

The next sentence is that Sebentar lagi udah mau hari ulang tahun saya. The use of the words ' $u d a h$ ' and ' $m a u$ ' in the standard language is certainly incorrect because these words are included in various informal conversations. So, the sentence should be written as sebentar lagi saya akan ulang tahun (Soon, it will be my birthday).

Next, the sentence of Bukit Bintang yang di atas gunung biar bisa lihat kota create an ambiguity because there is a mixture of several informal words, such as 'biar' and 'bisa'. The sentence is ideally changed to Bukit Bintang letaknya di atas gunung supaya dapat melihat kota (Bukit Bintang located on top of a mountain so that you can see the city).

Based on the data analysis above, it can be concluded that the BIPA students at the beginner level tend to make mistakes because they lack understanding of the meaning of the word, procedures for writing words with affixes, and arranging sentence structures. Understanding the standard Indonesian grammar is highly important for foreign students, especially those who take the BIPA classes for academic purposes.

In order to minimize the language errors of BIPA students in understanding and writing texts, the teachers or educators need to develop BIPA learning media related to writing affixes and composing effective sentences. By using the appropriate media, the students will more easily understand the diction also arrange sentences correctly. For instance, the use of flashcards is able to support the students' understanding by arranging the cards into a complete sentence with some affixes on them. Also, learning media development using digital devices can make it easier for students to access using gadgets.

\section{CONCLUSION}

According to the analysis of this study, most grammatical errors experienced by primary BIPA students were found when they wrote words, the structure of sentences, affixes, and word mixing either a foreign language or Indonesian slang in academic writing. It is certainly unavoidable in the language learning process, especially for beginner students who took the class for academic purposes. Errors are part of the process of using the Indonesian language correctly and adequately based on predetermined standards. BIPA students' language skills will increase by continuously practicing then they will also develop an intuitive sense of writing according to the standard Indonesian grammar.

\section{AUTHORS’ CONTRIBUTIONS}

Author 1 conducts data collection and analysis, while author 2 conducts data collection and analysis and writes ideas in the article. Then, author 3 conducts data collection and deepens the material.

\section{ACKNOWLEDGMENTS}

The authors are grateful to the International Conference on Cultural Studies and Applied Linguistics (The 2nd ICCSAL) to share ideas from our team. Also, we are thankful for BIPA Universitas Negeri Surabaya students, specifically beginner class, who support our materials.

\section{REFERENCES}

[1] H. Alwi, S. Dardjowidjojo, H. Lapoliwa, and A. M. Moeliono, Tata Bahasa Baku Bahasa Indonesia. Jakarta: Balai Pustaka, 2010.

[2] H. G. Tarigan, Menulis sebagai Suatu Keterampilan Berbahasa. Bandung: Percetakan Angkasa, 2008.

[3] V. Kiparsky, Russische Historische Grammatik. Heidelberg: Carl Winter, 1975.

[4] H. C. Dulay, M. K. Burt, and S. Krashen, Language Two. New York: Oxford University Press, 1982.

[5] E. N. Siagan, "Analisis kesalahan berbahasa (tulis) mahasiswa BIPA tingkat lanjut Universitas Yale, USA," in FKIP e-Proceeding, pp. 11-22, 2017.

[6] G. Susanto, "Pengembangan bahan ajar BIPA berdasarkan kesalahan Bahasa Indonesia pemelajar asing," Jurnal Bahasa dan Seni Fakultas Sastra Universitas Negeri Malang, vol. 35, no. 2, pp. 231$240,2007$.

[7] H. G. Tarigan and D. Tarigan, Pengajaran Analisis Kesalahan Berbahasa. Bandung: Angkasa, 1988.

[8] S. Sugiyono, Metode Penelitian Kuantitatif, Kualitatif, dan R\&D. Bandung: Alfabeta, 2016.

[9] H. G. Tarigan, Analisis Kesalahan Berbahasa. Jakarta: Depdikbud, 1997.

[10] M. Mustakim, Bentuk dan Pilihan Kata. Jakarta: Pusat Pembinaan, Badan Bahasa, 2016. 